\title{
Psikologi Positif Melalui Humor dalam Menumbuhkan Kesehatan Mental
}

\author{
Reghifa Khalimatus Syadiyah ${ }^{1}$, Risma Hesti Yuni Astuti ${ }^{2}$, Firna Aprilliani ${ }^{3}$ \\ UIN Walisongo, Semarang Indonesia ${ }^{123}$ \& 4 \\ reghifa7_1901016004@studentwalisongo.ac.id*
}

Article Information:

Received September 17, 2021

Revised Oktober 4, 2021

Accepted November 16, 202

Keywords: Humor, Psikologi Positif, Kesehatan Mental.

\begin{abstract}
In this era, technology is developing rapidly. Technological developments have a good impact but also have a bad impact on users. A good impact will certainly bring benefits to its users while a bad impact will bring problems. This can lead to problems related to mental health. Various pressures can trigger problems that can lead to stress, worry, sadness, moodiness, lack of enthusiasm, frustration to despair. In situations like this, positive emotions are needed to help relieve the pressure that is felt. One of the positive psychology that can be done is through humor. Humor can be both good and bad emotions. Humor is said to be bad done in excess so that it hurts the person concerned. Conversely, good humor will provide a sense of relaxation and calm for the person. Many people have the notion that humor is just a light joke that causes a sense of pleasure to release happy laughter. But it turns out that humor has a great function in it. Research conducted, that humor has an important role in mental health. Positive psychology of humor helps a person to reduce stress in his mind and heart so that it can help his problems. Research conducted on adolescents shows that a lot of stress is experienced by students. This proves that humor can be a coping mechanism for adolescents. In this study, the researcher used a descriptive qualitative method which aims to test the effectiveness of humor in helping to grow mental health and helping facilitate problem solving.
\end{abstract}

\section{PENDAHULUAN}

Dalam kehidupan sehari-hari banyak hal yang kita lewati. Namun terkadang jarang sekali menemukan sesuatu hal yang dapat membuat kita tertawa. Yang sering kita jumpai dan kita ingat adalah kesedihan, kekhawatiran hingga timbul tangisan. Banyaknya kesulitan dalam hidup baik yang berasal dari luar seperti di lingkungan keluarga, pertemanan, maupun di lingkungan masyarakat dan berasal dari dalam diri sendiri dapat mempengaruhi emosi kita (Istiningtyas, 2014). Menurut Bennet, emosi memiliki peran penting terhadap manusia walaupun emosi yang timbul tidak selalu dalam bentuk emosi yang baik (Hartanti, 2008). Emosi yang terlalu berlebih dapat menjadi hambatan bagi proses berpikir, yang dapat mengakibatkan seseorang kurang konsentrasi dan mempengaruhi produktivitas dan kreativitas seseorang. 
Hal demikian justru akan berakibat buruk terhadap kesehatan mental. Salah satu cara yang dapat dilakukan untuk menekan stress, khawatir, kesedihan, dan emosi negative lainnya yang berakibat pada kesehatan mental adalah dengan menggunakan psikologi positif humor.

Menurut Martin, humor mengandung energy yang positif. Humor dapat digambarkan sebagai suatu cara untuk menurunkan ketegangan dan kecemasan. Dengan menurunnya tingkat ketegangan yang dialami seseorang dapat memungkinkan seseorang berpikir tentang penyelesaian masalahnya (Ni Luh Deliyani, 2015). Kemungkinan seseorang memiliki berbagai penyelesaian masalah merupakan bentuk healing sebagai suatu metode atau terapi. Rangsangan humor dapat diperlukan mengingat sebagian orang menghadapi sulitnya tertawa dengan alasan yang tidak jelas.

Penelitian yang dilakukan sebelumnya tentang humor dan kaitannya dengan kesehatan mental menjadi referensi yang cocok bagi peneliti. Humor yang positif akan membawa dampak yang sehat bagi kesehatan mental. Saat ini masih banyak orang yang mengalami burnout terutama kalangan pelajar. Untuk itu dilakukan inovasi humor dengan audio visual. Hal ini menunjukkan bahwa humor dapar membantu siswa dari keadaan burnout (Rahmawati, 2017).

Penelitian yang dilakukan oleh Trifonia mengenai efektivitas terapi tawa untuk menurunkan tingkat depresi pada lansia sangat sesuai dengan penelitian yang saya lakukan. Masa lansia merupakan masa yang pasti dialami oleh manusia dan tentunya dimasa tersebut lansia menginginkan berkumpul dan bahagia bersama anak dan cucunya. Namun tak semua lansia mendapatkan kesempatan tersebut karena beberapa factor. Hal tersebut mengakibatkan sebagian lansia mengalami stress hingga depresi terutama bagi lansia yang hidup di panti jompo (Amir, 2005). Untuk alasan tersebut maka dipilihlah terapi tertawa untuk meningkatkan kesehatan mental pada lansia. Penelitian menunjukkan bahwa lansia yang sudah melakuan terapi tertawa cenderung lebih mentalnya dikarenakan terapi tertawa membuat lansia lebih rileks dan dapat melupakan sejenak apa yang menjadi bebannya selama masa usianya. Artinya bahwa humor memiliki manfaat tinggi sebagai menumbuhkan kesehatan mental pada usia lanjut (Trifonia Sri Nurwela, 2015). Sejalan dengan penelitian di atas, penelitian mengenai peningkatan sense of humor untuk menurunkan kecemasan pada lansia oleh Retna ini sesuai dengan penelitian yang saat ini dilakukan. Dalam penelitian ini menjelaskan bahwa lansia lebih mudah mengalami kecemasan bahkan pada hal-hal sepele. Hal ini mendorong pengupayaan kebahagiaan bagi para usia lanjut dengan cara memberikan pencegahan dan perawatan permasalahan kecemasan yang dialami. Salah satu upayanya adalah dengan terapi humor. Dengan adanya humor diharapkan lansia akan terstimulus agar dapat tertawa dan merasa gembira sehingga dapat menurunkan kecemasannya dan akan berakibat baik terhadap kesehatan mentalnya (Wahyuni, 2019).

Penelitian lain yang sejalan penelitian yang saat ini sedang dilakukan adalah mengenai kepekaan humor dengan depresi pada remaja ditinjau dari jenis kelamin oleh Ayu Fitriani. Remaja merupakan peralihan dari masa anak-anak ke masa dewasa. Dalam masa ini terjadi banyak perubahan baik fisik maupun psikis yang menyebabkan berbagai permasalahan tak terkecuali remaja laki-laki. Banyak hal yang menjadi stressor dan penyebab depresi seperti masalah percintaan, gaya hidup, penampilan, dan lain sebagainya. Sehingga stress dan depresi ini mempengaruhi prestasi. Salah satu upaya menangani hal di atas adalah dengan menggunakan humor. Nyatanya seseorang yang memiliki kepekaan humor tingga akan lebih ceria dan memiliki kebahagiaan lebih sehingga humor menjadi coping stress untuk menghindarkan dari stress dan depresi sehingga baik untuk kesehatan mental remaja (Hidayah, 2012).

Penelitian yang dilakukan oleh Mia Tri Anggraini tentang pengaruh tayangn humor dan hubungannya pada tingkat stress mahasiswa menjadi salah satu rujukan untuk jurnal ini. Masa sekarang banyak sekali media yang memberikan tayangan mengenai hal yang berbau lelucon atau humor. Mahasiswa tentu tak lepas dari berbagai macam kesibukan yang sering kali menyebabkan tekanan pada dirinya. Sejalan dengan penelitian yang sedang dilakukan, dengan melihat tayangan humor dimaksudkan agar mahasiswa senang dan tertawa. Hasil penelitian 
menunjukkan bahwa dengan melihat tayangan humor dapat menurunkan tingkat stress sehingga dapat membantu kesehatan mental (Budhiningthiyas, 2019).

Salah satu bentuk humor yang sering dijumpai adalah komedi. Seiring dengan berkembangnya teknologi, masyarakat lebih mudah mendapatkan hiburan melalui komedi. Acara komedi banyak bermunculan baik di televisi maupun media internet. Terdapat beberapa acara komedi yang dapat menjadi sarana untuk healing diantaranya program Opera Van Java di Trans7, Ini Talkshow dan Tonight Show di NET TV, Lapor Pak di Trans7, Baper di RCTI, dan masih banyak lagi. Program talk show komedi tonight show menjadi pilihan yang banyak digemari. Acara talkshow sebagai media komunikasi yang telah hadir sejak lama (Hasanah, 2017).

Humor memiliki manfaat dalam menumbuhkan kesehatan mental. Beberapa upaya telah dilakukan salah satunya upaya menumbuhkan kesehatan mental melalui humor pada gangguan stres. Stres dapat dialami oleh siapa saja tanpa melihat apapun. Stres kerja adalah salah satu contoh yang banyak dialami. Stres yang dialami oleh karyawan dapat mengakibatkan penurunan produktivitas kerja hingga gangguan kesehatan seperti penyakit jantung. Stressor tiap orang berbeda-beda yang menyebabkan tingkat stress pada tiap orang juga berbeda. Untuk itu, beberapa perusahaan menggunakan humor untuk membantu mengurangi stress pada kayawannya. Kepekaan humor memiliki pengaruh yang cukup baaik ebagai upaya coping stress pada karyawan. Jika coping tidak dilakukan dengan baik maka akan kurang efektif bagi orang yang sedang mengalami stress. Ini artinya upaya yang dilakukan bahwa semakin tinggi kepekaan homor seseorang maka semakin tinggi pula kemungkinan keberhasilan untuk menurunkan stress begitu juga sebaliknya sehingga memungkinkan dengan humor dapat menumbuhkan kesehatan mental (Priambodo, 2016).

Stres dapat diakibatkan salah satunya karena factor pekerjaan. Stres dapat menimbulkan permasalahan baik pada perilaku, psikologis, maupun fisiologis. Stres harus diatasi secara tepat agar tidak berlanjut hingga terganggunya kesehatan mental seseorang. Stres harus segera ditangani salah satunya menggunakan metode coping. Salah satu cara coping yang mulai banyak digunakan adalah dengan humor. Hasil penelitian baru-baru ini menunjukkan bahwa selera humor seseorang dapat menjadi coping stress yang artinya dapat membantu menumbuhkan kesehatan mental. Semakin tinggi selera humor seseorang maka semakin rendah tingkat stress seseorang yang hal itu menunjukkan tingkat kesehatan mental yang baik (Ramadhani, 2021).

Upaya lain yang dilakukan adalah dengan terapi tawa. Penelitian yang dilakukan oleh Feri Hardi menyatakan bahwa terapi tawa dapat membantu menurunkan kecemasan. Dengan tertawa satu menit tubuh akan mengeluarkan hormone endhorpin yang menyebabkan tuh menjadi rileks. Hal inilah yang digunakan sebagai dasar bahwa dengan humor dapat menumbuhkan kesehatan mental (Feri hardi, 2018).

Semakin ke sini program talkshow sudah mulai beralih menjadi acara yang lebih menarik minat masyarakat. Salah satu programnya adalah acara tonight show. Program tonight show tak hanya acara talkshow biasa yang memberikan informasi namun juga menyajikan komedi yang cukup segar bagi para pemirsanya. Komedi yang disajikan cukup mengundang tawa dengan para pengisi acara yang lucu membuat acara tonight show menjadi alat untuk membantu meringankan beban pikiran dan kecemasan. Dengan ini, acara komedi atau humor menjadi alternatif yang menjanjikan bagi seseorang yang memiliki permasalahan berat dengan psikologi positif.

\section{METODE PENELITIAN}

Dalam jurnal ini kami menggunakan metode penelitian kualitatif deskriptif (naturalistic inquiry). Kualitatif deskriptif adalah jenis metode penelitian yang dilakukan dengan memanfaatkan data kualitatif yang selanjutnya dijabarkan secara deskriptif. Umumnya, metode ini digunakan untuk menganalisis kejadian, fenomena ataupun kondisi secara sosial sesuai dengan tema penelitian kami. Selain itu, metode ini dipilih karena lebih menekankan pada hasilnya dengan menampilkan hasil data yang transparan tanpa adanya rekayasa maupun manipulasi proses penelitiannya. Obyek dalam penelitian ini adalah program TV yang bernuansa 
comedi yaitu Opera Van Java dan Lapor Pak di Trans7 serta Tonight Show di NET TV. Sedangkan subyek penelitiannya adalah Penonton program TV Comedi dalam acara TV seperti Opera Van Java dan Lapor Pak di Trans7 serta Tonight Show di NET TV. Adapun tujuan dari penelitian ini, untuk mengetahui pengaruh Psikologi Positif dengan Humor terhadap Kesehatan mental melalui program TV comedi. Selain itu kami mengulas humor di masa Rasulullah dan umat Muslim terhadap karakteristik humor yang sesuai dengan ajaran agama Islam.

Sumber data penelitian merupakan salah satu unsur yang sangat penting karena sumber data berkaitan dengan kualiatas dari hasil penelitian. Kami menggunakan dua sumber data yaitu data primer dan data sekunder. Adapun pengertian dari data primer adalah data yang didapatkan langsung melalui subjek penelitian. Di sini kami mendapatkan mendapatkan data maupun informasi melalui observasi terhadap situs-situs yang dimiliki program TV yang bernuasa komedi. Sedangkan data sekunder merupakan data yang diperoleh dari sumber data yang sudah tersedia. Data yang digunakan berasal dari jurnal penelitian terdahulu maupun literatur yang kami kutip sebagai referensi. Dalam hal ini kami mengambil penelitian terdahulu yang dikutip dari jurnal pada google scholar sebagai wadah referensi kami. Selain itu, kami selaku peneliti mencoba membandingkan karakteristik humor di dalam acara komedi yang sudah kami pilih yaitu Opera Van Java dan Lapor Pak di Trans7 serta Tonight Show di NET TV terhadap kesehatan mental penontonnya. Oleh karena, objek penelitian menggunakan elektronik/online maka kami melakukan penelitian lebih lanjut dengan observasi atau pengamatan mendetail yaitu mengakses situs-situs yang dimiliki oleh ketiga program TV tersebut diantaranya Youtube, Twitter dan instagram. Dalam mengakses situs-situs tersebut, kami mengobservasi dan mengamati detail komentar yang disediakan sebagai respon dari mereka atas program TV tersebut.

\section{PEMBAHASAN}

\section{Hasil}

Analisa data dalam penelitian ini menggunakan metode penelitian kualitatif deskriptif (naturalistic ingury), pengumpulan data dalam penelitian ini menggunakan dua sumber data yaitu observasi situs-situs dan data yang diperoleh dari jurnal terdahulu maupun literatur yang dikutip dari beberapa refrensi sebagai pedoman pengumpulan data untuk mengetahui hasil dari karakteristik humor didalam acara komedi. Verifikasi data yang digunakan dalam penelitian ini dengan cara triangulasi. Triagulasi di dalam integritas ini dimaksudkan sebagai pemvalidasikan data dari berbagai sumber dengan berbagai cara dan waktu (Sugiono,2013).

Karakteristik program acara Tonight Show memuat banyak informasi dan hiburan di dalamnya, selain dikemas dengan humor berupa games-games seru yang membuat penonton tertawa ternyata informasi yang diberikan membuat acara ini menjadi lebih banyak pengetahuan. Sehingga Tonight Show sangat menghibur dan informatif bagi penonton dirumah. Sasaran segmentasinya adalah kaum remaja dan dewasa. Oleh karena konten yang dikandungnya tersebut, para penonton setianya menjadi lebih senang setelah beraktivitas seharian terlebih dengan jam tayang yang malam sesuai dengan waktu mendekati istirahat. Megantara, 2021).

Karakteristik program acara OVJ menampilkan budaya Jawa dengan balutan cerita yang menarik, yaitu cerita tentang seorang dalang yang ditemani oleh sinden yang bernyanyi ketika wayang wong (para pemain) memulai adegannya dengan iringan musik gamelan. Keunikannya berasal dari wayang wong yang terkesan tidak mengikuti arahan dari dalang maupun formulasi kisah yang sebenarnya, mereka bertindak sesuka hati namun menghasilkan hiburan yang menarik. OVJ menjadi penyajian yang istimewa karena berada pada kondisi butuh acara hiburan dan kelebihannya yang berbalut budaya dan seni rakyat (dikutip dari https://repository.uksw.edu/bitstream/123456789/6984/3/T1_362009060_BAB\%20III.pdf).

Karakteristik program acara Lapor Pak! Yaitu mengusung konsep komedi varietas, Lapor Pak! dikemas melalui sketsa dan gelar wicara dengan latar belakang kantor polisi yang mengkomedikan kasus-kasus kriminal, isu terkini, dan gosip artis dengan cara penyampaian yang mengundang gelak tawa. Kelucuan semakin menjadi saat para pemain sedang bertugas 
menginterogasi saksi dan tersangka yang dimainkan oleh bintang tamu. Acara ini mendapatkan sambutan yang hangat dari masyarakat pencinta humor. Di mana hadir ketika maraknya berita yang menegangkan dan isu terhangat lainnya, guyonan yang dihadirkan membuat kesegaran dengan kisah keseharian seputar proses penanganan kasus kriminal dan kejahatan dalam kemasan canda. Namun acara ini tidak hanya mengangkat humor tetapi juga mengangkat tentang pengingat diri supaya lebih kritis dan berani speak up (Artari, 2021).

\section{Diskusi}

\section{Pengertian Humor}

Kata humor berasal dari bahasa Yunani yang artinya getah. Pada kenyataannya, humor diartikan sebagai suatu keadaan gembira secara perilaku dalam kehidupannya baik kepada dirinya maupun sekitarnya. Menurut pendapat Arwah Setiawan (dalam Rahmanadji, 2009) dijelaskan bahwa humor merupakan suatu keadaan atau perasaan yang membuat seseorang mengekspresikan tawa bahagia secara mental yang diwujudkan secara rasa dan dalam keadaan sadar dari dalam diri kita yang biasanya menimbulkan senyum hingga tertawa.

Humor adalah suatu sifat yang utuh yang dapat merangsang timbulnya kemauan tertawa (Fitriani, 2012). Humor juga dapat dikatakan suatu sarana komunikasi social (Rahmanadji, 2007). Ross berpendapat, menurutnya humor merupakan suatu hal yang digunakan untuk menarik perhatian dengan senyum dan ekspresi tawa.

\section{Fungsi Humor terhadap Kesehatan Mental}

Fungsi Humor terhadap Kesehatan Mental berdasarkan jurnal penelitian yang peneliti temukan dari studi kepustakaan yang dikutip dari jurnal Listya I., tentang humor dilihat dari Psikologi Islam, bahwa fungsi humor diklasifikasikan berdasarkan beberapa bidang, yaitu :

a. Bidang Kesehatan Fisik

Menurut hasil dari Penelitian yang dilakukan Dr. L. Berk dan Dr. S. Tan berkaitan pengaruh tertawa terhadap sistem kekebalan tubuh, menunjukkan bahwa tertawa membawa dampak positif untuk kesehatan, misalnya menambah jumlah dan kapasitas sel kekebalan yang bertanggung jawab untuk melawan sel virus yang membahayakan tubuh; menaikkan tingkat sejumlah antibodi yang melawan infeksi saluran pernapasan atas; meningkatkan aktivitas diafragma, layaknya pada senam aerobik. Hal tersebut membuat kemampuan tubuh untuk mengelola oksigen menjadi meningkat. Selain itu, humor juga membantu dalam proses menghilangkan sakit dan menambah tingkat kualitas hidup seseorang dengan penyakit yang mengancam jiwa (Franzini, 2001).

Banyak artikel di berbagai media populer mengklaim bahwa humor telah terbukti secara ilmiah mengurangi gejala alergi, meningkatkan penyembuhan pada tubuh yang sakit, memperkokoh pertahanan tubuh, menurunkan kerentanan penyakit stroke dan penyakit berbahaya lainnya dan ternyata humor juga ikut menolong tubuh untuk mengendalikan kadar gula darah yang dimiliki orang-orang tersebut. Selain itu, berdasarkan kepercayaan khayalak umum bahwa tingkat manfaat kesehatan dari humor/tawa kurang menguntungkan. Hal ini dikarenakan, data yang tersedia tidak men-support dan tidak ada bukti yang menguatkan bahwa humor/tawa memiliki manfaat instan bagi kesehatan, atau manfaat kesehatan mental sebenarnya. Namun, sekilas tampak lebih nyata, karena peningkatan kesehatan fisik sebagai akibat dari peningkatan kesehatan mental, salah satunya bersumber dari humor.

b. Kesejahteraan Psikologis

Humor berdampak pada kesejahteraan psikologis karena humor dianggap dapat membangkitkan emosi positif sehingga dirinya merasa bahagia dan energik, mengurangi tertekan, cemas dan rasa mudah tersinggung bahkan pada titik tertentu, emosi negatif yang dirasakan menghilang. Hal inilah yang menciptakan perasaan sejahtera. Mudahnya seperti 
ini, semakin meningkatnya humor, semakin bertambah pula energi positif dengan begitu semakin meningkat juga kemunculan rasa sejahtera.

Sebuah penelitian yang berhubungan dengan humor dan emosi adalah bahwa humor dapat mengurangi suasana hati yang negatif, mempengaruhi cara melihat hidup dengan lebih banyak harapan, menurunkan rasa kebosanan dalam pengerjaan tugas, dapat memunculkan emosi positif dengan cepat, memiliki dampak yang setara bahkan lebih baik daripada melakukan pelatihan fisik berat. Selain itu, humor memiliki keterkaitan yang lemah dengan emosi negatif seperti gangguan mood, ketakutan dan kecemasan, depresi, kekacauan emosional, ataupun rasa kekhawatiran dengan masalah hidup. Tanpa humor saja, sekadar tersenyum dan tertawa sendiri, dapat membangkitkan emosi positif, meskipun dengan durasi yang lebih singkat dan bersifat sementara

Namun demikian, selain dampak positif terdapat sebagian humor yang tidak menyehatkan. Humor tersebut meliputi dua gaya humor. Pertama, gaya berhumor agresif adalah humor yang digunakan untuk mengkritik bahkan memanipulasi orang lain, seperti humor aliran sarkasme, berhumor dengan olok-olok, dan meremehkan bahkan bersifat rasis. Sedangkan gaya berhumor menyalahkan diri adalah humor yang dilakukan dengan mengorbankan diri sendiri untuk membahagiakan orang lain, hal ini dapat berupa menjelekjelekkan diri secara berlebihan supaya terkesan lucu, sehingga ia dapat terbahak-bahak dengan orang lain.

c. Hubungan Sosial

Akibat dari banyaknya orang yang menikmati humor karena kemunculan emosi positif, tidak mengherankan ketika orang yang humoris dalam pergaulannya dianggap sebagai individu yang menyenangkan dan membuatnya lebih banyak terlibat dibandingkan yang tidak humoris. Kaitannya dengan hubungan sosial Franzini (2001) mengungkapkan pendapatnya bahwa humor merupakan stimulus sosial yang membahagiakan dan dapat mempererat hubungan dengan teman. Selain hal itu, masih ada beberapa manfaat humor jika ditinjau dari hubungan sosial, yaitu:

1) Dunia Keluarga. Humor dapat mempengaruhi tingkat kepuasan terhadap pasangan (rumah tangga atau dalam pacaran). Pendapat tersebut didukung fakta bahwa pasangan dengan selera humor yang tinggi pasangannya lebih bahagia. Karena individu yang memiliki selera humor yang baik dapat mengurangi tingkatan stres yang dialami pasangannya. Hubungan pasangan dengan humor yang menyenangkan diketahui menghasilkan kualitas yang lebih tinggi dan hubungan yang lebih memuaskan.

2) Dunia Kerja. Meskipun tertawa bersama atasan dalam lingkungan kerja dianggap tabu namun humor menjadi bagian penting. Hal ini dipicu berbagai penelitian dengan menghasilkan bahwa humor efektif dalam menambahkan tingkat produktivitas kerja dan meningkatkan efektivitas organisasi. Misalnya saja, dengan adanya humor maka komunikasi bisnis lebih lancar. Selain itu, humor mencegah bahkan mengurangi tingkat stres dari pekerjaan.

3) Dunia Akademik. Humor dapat menjadi salah satu cara untuk meningkatkan daya ingat. Proses belajar mengajar yang menerapkan humor didalamnya, dapat memberikan perkembangan yang signifikan bagi dunia pendidikan salah satunya meningkatkan hasil belajar muridnya. Ahli penelitian mengklaim bahwa penggunaan humor dapat meningkatkan daya ingat. Humor berpengaruh positif terhadap program pendidikan karena humor dapat memicu dan merangsang daya ingat, meningkatkan kreativitas, menjadi sebuah motivasi, mengurangi stres belajar, dan memberikan positive vibes terlebih dalam komunikasi yang terjalin antara guru dan siswa. 


\section{Efektivitas Humor Pada Acara Tonight Show}

Berdasarkan hasil dari wawancara beberapa orang maka didapatkan hasil bahwa humor di acara tonight show dapat membuat penontonnya mengurangi kecemasan dan juga mengembalikan mood, serta dapat menurunkan tingkat depresi seseorang. Beberapa orang yang menonton tonight show ini memberikan respon emosi positif seperti tertawa, ada juga yang tertawa hingga menangis, serta bertepuk tangan sehingga tanpa sengaja mendorong teman disampingnya dan juga tersenyum. Seseorang yang mulanya tidak ingin berbicara ataupun sedang dendam sehingga mulai mau menyapa, tertawa bersama-sama saat menyaksikan siaran ini.

Dari komentar-komentar penonton acara tonight show ini sebagian orang mengungkapkan perasaannya senang, bahagia dan mengatakan nyenyak tidur, dapat menghilangkan stress dan lelah setelah beraktifitas seharian. Seseorang yang mulanya tidak ingin berbicara dengan temannya yang bermusuhan memperlihatkan perubahan yang lebih positif, sehingga mereka bisa akrab dan tertawa bersama-sama. Sikap penonton melihatkan respon emosi yang positif, dapat berhubungan dengan menggunakan humor, sehingga dapat melihat masalah dari sudut pandang yang berbeda, tidak mengalami gangguan tidur, merasakan kenyamanan dan mulai menikmatinya, dan selalu positif thingking.

Berdasarkan teori Martin yang diperoleh melalui hasil penelitian pada 2010, humor sebenarnya berisi emosi positif. Emosi positif itu dapat diartikan sebagai suatu cara yang dapat digunakan sebagai usaha menurunkan tegangan (tension) serta dapat mengurangi rasa kecemasan (anxiety). Hal ini alhasil bias menimbulkan individu menjadi berpikir fleksibel, yang didiperlukan ketika adanya kemungkinan- kemungkinan penyelesaian permasalahan yang saat ini dialami. Keahlian memandang bermacam-macam kemungkinan penyelesaian permasalahan ialah bukti jika dalam proses terapi diri seseorang terjadi masa penyembuhan (healing).

Humor yang berisi proses the social context of humor yaitu humor yang berisi kejadian sosial, humor bisa terjadi pada kejadian social apa saya hingga adanya humor, seseorang dapat berhubungan dengan baik. Proses yang kedua yaitu cognitive-perceptual processes in humor dengan humor ini bisa dilakukan dengan memproses mental individu dengan cara menggali informasi baik dapat berasal dari lingkungannya atau memori otaknya, lewat perkataan atau ide-ide dan juga perilaku yang kreatif untuk bisa mendapatkan kata atau ide yang memukau dan suatu prilaku yang dianggap lucu bagi orang lain. Proses ketiga yaitu emotional aspects of humor dalam proses ini individu akan memperlihatkan reaksi senang dari batinnya. Menurut Martin (2010), pada proses keempat laughter as an expression of the emotion of mirth dimaksudkan adanya humor maka seseorang akan menampilkan raut wajah yang gembira, membahagiakan dalam wujud tawa, senyuman, tawa yang lepas, dan juga menunjukan gerak badan seperti tepuk tangan, memukul, mengeluarkan air mata saat tertawa, wajah yang memerah dan sebagainya

Humor sendiri mempunyai emosi positif yaitu kebahagiaan, ketertarikan, cinta, kegembiraan, perasaan lega atau kepuasan hati serta rasa bangga. Pada emosi dan social, humor juga memberikan pengaruhnya secara kongitif pada individu, hingga pada kognitif mengalami perubahan yaitu dengan berfikir secara fleksibel, dapat melihat permasalahan dari berbagai sudut pandang yang berbeda, selalu befikir positive, dan dapat mencari solusi dalam permasalahan yang di hadapinya. Humor sendiri dapat menggantikan emosi negatif seperti marah, stress, cemas, ataupun depresi sehingga menjadikan energi yang lebih positif dan dengan adanya humor hubungan akan lebih menyenangkan (Martin, 2010). Humor sendiri bisa menurunkan tingkat kecemasan dari seseorang individu. Humor yang efektif adalah humor yang dapat membantu turunnya kecemasan dan stres. Hal ini dikemukakan oleh Bennet (1997). Berdasarkan penelitian Martin \& Lefcourt (1983) menyatakan humor juga dapat meningkatkan kualitas hidup dari seseorang.

\section{Humor Dalam Pandangan Islam}

Humor memiliki magnet yang digunakan untuk menarik manusia agar memiliki 
pengaruh baik bagi fisik dan kesehatan mental. Humor dapat menimbulkan senyum dan tawa. Menurut Amin "Andai saja manusia dapat bersikap jujur, maka manusia tidak akan memerlukan obat-obatan yang dijual di Apotek, cukup di obati dengan senyum dan tawa tanpa ada obat penenang" (Al-Qarni, 2005). Menurutnya orang yang mudah tersenyum akan memandang permasalahannya dengan hati yang tenang sehingga diharapkan dapat memecahkan kesulitannya.

Dalam Islam sendiri, humor diperbolehkan saja asalkan tidak berlebihan. Humor juga merupakan sarana kebahagiaan, dengan senyuman sangat dianjurkan sebagai bentuk keramahan hati. Senyum sangat dianjurkan sebagai bentuk kesenangan yang merupakan hak tiap manusia (Marwan, 2013).

Dalam pandangan filsuf, humor dapat digunakan sebagai bentuk representasi hati dan bentuk kelapangan dada dari jiwa seseorang. Hal ini sekaligus mencerminkan keshalehan dan kecerdasannya. Humor dianggap sebagai strategi yang cocok digunakan untuk mengomentari, menertawakan kebodohan, dan mengetahui sisi lain sebuah wawasan dengan cara yang bijaksana. Banyak sekali tokoh Islam yang digambarkan dengan karakter yang unik, bodoh, nyeleneh, dan menunjukkan sikap yang berbeda. Tokoh tersebut diantaranya adalah Bahlul, Abu Nawas, Nasruddin Hoja, dan masih banyak tokoh lainnya.

Tokoh-tokoh di atas seringkali dikaitkan dengan humor sufi. Humor sufi merupakan humor dengan topik pembahasan agama Islam. Humor sufi merujuk pada ajaran-ajaran tasawuf dengan kandungan Alquran dan Hadis. Kejenakaan humor ini lebih mudah dipahami dan dinikmati apabila seseorang tersebut mengenal serta memahami ajaran tasawuf. Biasanya, disajikan dengan bentuk kisah keteladanan seseorang dan pengalaman spiritual, namun juga bisa berbentuk nasihat kebijaksanaan dan pemikiran sufistik. Hal ini dikarenakan, humor sufi membawa misi dakwah, sehingga topiknya lebih menekankan pada perenungan, mawas diri, dan lebih membuat berpikir daripada mengundang kelucuan ataupun sekadar senyuman. Pada dasarnya, humor yang dihadirkan setidaknya dapat membuat individu tersebut lebih mengenal dirinya dan Tuhannya serta lebih mendekatkan diri kepada Tuhan (Marwan I, 2013).

Hal ini diperkuat dengan jurnal penelitian karya Khalid Ramdhani yang berjudul Akhlaq Humor Dalam Pendidikan Islam, yang mengatakan bahwa Rohmadi berpendapat tentang fungsi humor sufi, meliputi: (Ramadhani K, 2019)

a. Sebagai media penalaran. Humor sufi memiliki fungsi untuk mengasah otak dan wadah penalaran, misalnya dalam pembelajaran dan diskusi, serta pembicaraan santai namun berbobot.

b. Sebagai motivasi diri. Humor sufi memiliki fungsi motivasi artinya humor dapat memotivasi diri sendiri serta orang lain supaya melakukan kebaikan, menegakkan kebenaran dan bermanfaat bagi umat. Harapannya, dengan humor sufi seseorang menjadi lebih dekat dengan Tuhan dan dapat membantu orang tersebut meningkatkan amalan kebaikannya sebagai bahan persiapan untuk akhirat kelak.

c. Sebagai bahan kritikan dan mengajak berpikir kritis. Humor sufi memiliki kandungan agama yang bermanfaat sebagai pengingat serta bahan perenungan hidup dibandingkan dakwah dalam bentuk zikir aqliyah yaitu zikir dengan mengandalkan pemikiran rasional/akal. Fungsi humor sufi ini tertuang dalam kisah seorang raja dan rakyatnya serta pengalaman spiritual seseorang. Hal ini sejalan dengan pendapat Derk (1980:13) yang mengatakan humor bukan sekadar mengundang respon emosional, lebih dari itu, merangsang dan memunculkan cara berpikir kritis untuk merenungi kandungan di dalamnya.

d. Media dakwah agama. fungsi utama dari humor ini adalah tersampaikannya pesan agama serta risalah para Nabi dan Rasul. Meskipun bersifat humor namun Humor sufi memiliki muatan nilai-nilai agama yang bersifat intrumental dan fundamental. 
Sebagaimana fungsi d, humor sufi memiliki nilai-nilai keIslaman sebagai berikut : pertama, Nilai Akidah, nilai ini ditunjukkan dengan sikap dan keyakinan seseorang terhadap keimanan kepada Allah beserta ciptaan-Nya, dan mempercayai alam gaib berkaitan dengan Kematian dan alam kubur. Kedua, Nilai Ibadah, nilai ini meliputi ibadah individual (fardhu 'ain) yaitu pemanfaatan hidup untuk ibadah serta mengimani fitrah, selanjutnya nilai ibadah kolektif (fardhu kifayah) berupa sebuah pengingat untuk tidak cinta dunia serta ajakan berbuat kebaikan. Ketiga, Nilai Muamalah, sebagaimana yang diketahui mualamah berhuhubungan dengan sesama, maka nilai ini menyangkut hubungan keluarga seperti kesakralan pernikahan, dan menyangkut hubungan masyarakat seperti adab terhadap tamu dan kepercayaan terhadap sedekah (Marwaan, I, 2013).

Selain itu, Nabi Muhammad SAW sendiri juga mempunyai sifat yang humoris. Nabi Muhammad SAW dikisahkan dalam hadits pernah mencandai seorang nenek. Ketika nenek bertanya kepada Rasulullah apakah dirinya kelak masuk surga? Maka Rasulullah menjawab tidak yang akhirnya menyebabkan nenek tersebut menangis. Akhirnya Rasulullah memberitahukan bahwa di surga memang tidak ada nenek-nenek melainkan nenek akan diubah menjadi gadis kembali (HR. Tabrani dan Baihaqi). Dari kisah ini dapat diartikan bahwa dalam islam sendiri ajarannya dapat disampaikan dengan cara yang ringan dan jenaka. Namun yang perlu diingat bahwa candaan yang dilontarkan Nabi Muhammad SAW tidak berdampak buruk dan tidak menyalahi fungsi homor sehingga boleh-boleh saja dan dilakukan tidak berlebihan.

Menurut penjelasan dari psikolog muslim, mengenai cara Islam memandang humor. Menurunya, humor memiliki banyak kegunaan baik secara fisik maupun mental. Selain itu, humor termasuk dalam ibadah, diantaranya sebagai bentuk sedekah, memberi kesan percaya diri, dan sebagai ketenangan batin. Selain itu, humor menandakan bentuk kebahagiaan dan kebaikan hati.

\section{Karakteristik Humor}

Berdasarkan penelitian yang dilakukan oleh Kurniawan pada 2017, terdapat beberapa cara humor antara lain memakai teknik kesalahpahaman, dengan permainan bungi, ironi, dan omomg kosong. Karakteristik humor memiliki unsur-unsur tuturan humor, diantaranya:

a. Penuturan yang berlebihan

Karakteristik humor yang pertama adalah gaya penuturan yang berlebihan dapat mengakibatkan perbedaan informasi yang diterima. Namun jika digunakan dalam hal humor, maka akan menyebabkan tuturan berlebihan tersebut menjadi suatu hal yang memiliki kelucuan tersendiri. Kelucuan tersebut diperoleh dari informasi yang disampaikan dengan cara yang tidak informative dan tidak sewajarnya. Dengan melakukan hal ini maka akan dibentuk kelucuan tersendiri dan dapat menciptakan humor.

b. Tuturan kibul

Tuturan ini dumanfaatkan untuk membentuk kelucuan dalam humor. Tuturan kibul adalah suatu perkataan yang tidak sesuai dengan apa yang terjadi sebenarnya. Tujuannya adalah agar keadaan yang sebenarnya terjadi tidak diketahui banyak orang. Jadi, tuturan humor ini dugunakan untuk menimbulkan tawa pada konteks humor walaupun tuturan kibul sangat bertolak belakang dengan prinsip. Semakin mengadangada, tidak sesuai fakta, dan dibuat-buat suatu informasi maka semakin tinggi pula tingkat kelucuannya.

c. Tuturan simpang

Faktor utama sebuah kelucuan dalam humor adalah tuturan simpang. Tuturan ini adalah tuturan yang dilakukan dengan mengalihkan arah pembicaraan yang saat ini sedang dibicarakan. Kualitas tuturan tersebut terjadi ketika dibelokkan atau melenceng dari topic yang sedang dibicarakan. 
d. Tuturan ambigu

Tuturan ambigu adalah salah satu penunjang dalam humor. Tuturan ambigu dianggap membingungkan saat dikatakan kepada orang lain karena memiliki makna ganda. Namun dalam sebuah humor perkataan yang ambigu dapat membantu menciptakan kelucuan tersendiri. Semakin ambigu perkataan yang diucapkan maka akan menimbulkan lucu pada humor yang dilakukan (Ratnawati, 2019).

\section{KESIMPULAN}

Dari hasil penelitian yang telah dilakukan dapat ditarik kesimpulan bahwa humor dapat menumbuhkan kesehatan mental dengan berbagai cara salah satunya ialah dengan cara menonton siaran tv comedi seperi acara tonight show cara ini sangat efektif untuk menurunkan kecemasan, menghilangkan stress dan memperbaiki mood pada penontonnya. Hal ini dapat dilihat dari adanya emosi positif yang dihasilkan sehingga terjadi perubahan rasa kecemasan dan mood sesudah dan sebelum menonton acara siaran tv comedi.

\section{Referensi}

Amir N.,.(2005). Depresi, Askep Neurobiologi Diagnosis dan Tata Laksan. Jakarta: Balai Penerbit FKUI.

Budhiningthiyas, M. T. (2019). Pengaruh Tayangan Humor Terhadap Tingkat Stres pada Mahasiswa Psikologi Unesa. Prosiding Seminar Nasional, 158-161.

Feri Hardi, S. d. (2018). Perubahan Kecemasan Lansia Setelah Diberikan Terapi Humor Tertawa. Jurnal Kesehatan dr. Soebandi, 49-53.

Fitriani, A. (2012). Kepekaan Humor dengan Depresi Pada Remaja ditinjau dari Jenis Kelamin. Jurnal Penelitian Psikologi, 81.

Hartanti. (2002). Peran Sense of Humor dan Dukungan Sosial Pada Tingkat Depresi Penderita Dewasa Pascastroke. Indonesian Psychological Journal, 107-119.

Hartanti. (2002). Peran Sense of Humor dan Dukungan Sosial Pada Tingkat Depresi Penderita Dewasa Pascastroke. Anima, Indonesian Psychological Journal, 107-119.

Hartanti. (2008). Apakah Selera Humor Menurunkan Stres? Sebuah Meta-analisis. Indonesian Psychological Journal, 38-55.

Hasanah, N. (2017). Persepsi Masyarakat Terhadap Program Acara Ini Talkshow di NET TV. Sumatera Utara: Universitas Sumatera Utara.

Hidayah, A. F. (2012). Kepekaan Humor dengan Depresi pada Remaja Ditinjau dari Jenis Kelamin. Humanitas, 77-89.

Istiningtyas, L. (2014). Humor dalam Kajian Psikologi Islam. Jurnal Ilmu Agama, 37-59.

Marwan, Iwan. (2013). Semiotika Humor Sufi. Surabaya: UIN Sunan Ampel Press.

Megantara. (2021) PERSEPSI MAHASISWA KOTA BANDUNG PADA PROGRAM ACARA TONIGHT SHOW

NET TV. Skripsi, FISIP UNPAS

N, Amir. (2005). Depresi, Askep Neurobiologi Diagnosis dan Tata Laksana. Jakarta: Balai Penerbit FKUI.

Nasution Amir. 2005. Depresi, Askep Neurobiologi Diagnosis dan Tata Laksana. Jakarta: Balai Penerbit FKUI.

Ni Luh Deliyani, M. S. (2015). Efektivitas Terapi Humor Dengan Media Film Komedi Untuk Menurunkan Tingkat Kecemasan Pada Lansia. Hospital Majapahit, 44-53.

Priambodo, A. W. (2016). Hubungan Antara Kepekaan Humor dengan Stres Kerja pada Pegawai Karantina Pertanian Kelas I Semarang Jawa Tengah. Psikologika, 47-55.

Rahmanadji, D. (2007). Sejarah,Teori,Jenis dan Fungsi Humor. Jurnal Penelitian Sastra, 220.

Rahmawati, B. Y. (2017). Pengaruh Humor Audio Visual Terhadap Burnout Study. Jurnal Penelitian Bimbingan dan Konseling, 127-140.

Ramadhani, Khalid. (2019). Akhlaq Humor dalam Pendidikan Islam. Jurnal Ilmu Agama Islam: Ta'lim. Vol 1, Nomor 1, 41 
Ramadhani, M. Y. (2021). Hubungan Antara Sense of Humor deangan Stres Kerja pada Pegawai. Acta Psychologia, 81-87.

Ratnawati, H. D. (2019). Karakteristik Tuturan Humor. Jurnal Ilmiah Pengantar Studi Pendidikan Bahasa dan Sastra Indonesia, 187-194.

Siska Artati. (2021). Ketawa Ngakak Bareng "Lapor Pak", dikutip dari https://www.kompasiana.com/siskaartati/615ba09f06310e7b6e7f3ea2/ketawa-ngakakbareng-lapor-pak pada 1 Desember 2021.

Sugiono. (2003). Metodologi Penelitian Kualitatif. Bandung: Alfa Beta.

Trifonia Sri Nurwela, M. S. (2015). Efektivitas Terapi Tertawa Untuk Menurunkan Tingkat Depresi pada Lanjut Usia. Jurnal Ilmiah Kedokteran, 62-76.

Wahyuni, R. F. (2019). Peningkatan Sense of Humor Untuk Menurunkan Kecemasan pada Lansia. Indonesian Journal of Islamic Psychology, 139-169.

Wijaya, E. (2017). Peranan Humor terhadap Stres dengan Subjective Well Being (SWB) sebagai Mediator pada Awal Dewasa. Jurnal Muara Ilmu Sosial, Humaniora, dan Seni, 353360.

https://repository.uksw.edu/bitstream/123456789/6984/3/T1_362009060_BAB\%20III.pdf pada 1 Desember 2021 